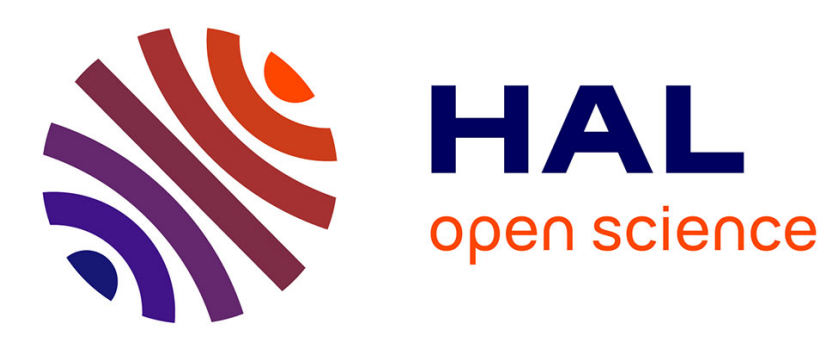

\title{
Enhancement of the superconducting transition temperatures in ion-implanted aluminium alloys
}

\author{
A.M. Lamoise, J. Chaumont, F. Lalu, Frédéric Meunier, H. Bernas
}

\section{To cite this version:}

A.M. Lamoise, J. Chaumont, F. Lalu, Frédéric Meunier, H. Bernas. Enhancement of the superconducting transition temperatures in ion-implanted aluminium alloys. Journal de Physique Lettres, 1976, 37 (11), pp.287-289. 10.1051/jphyslet:019760037011028700 . jpa-00231294

\section{HAL Id: jpa-00231294 https://hal.science/jpa-00231294}

Submitted on 1 Jan 1976

HAL is a multi-disciplinary open access archive for the deposit and dissemination of scientific research documents, whether they are published or not. The documents may come from teaching and research institutions in France or abroad, or from public or private research centers.
L'archive ouverte pluridisciplinaire HAL, est destinée au dépôt et à la diffusion de documents scientifiques de niveau recherche, publiés ou non, émanant des établissements d'enseignement et de recherche français ou étrangers, des laboratoires publics ou privés. 


\title{
ENHANCEMENT OF THE SUPERCONDUCTING TRANSITION TEMPERATURES IN ION-IMPLANTED ALUMINIUM ALLOYS (*)
}

\author{
A. M. LAMOISE, J. CHAUMONT and F. LALU \\ Laboratoire René-Bernas du Centre de Spectrométrie Nucléaire et de Spectrométrie de Masse, \\ 91406 Orsay, France \\ F. MEUNIER \\ Laboratoire de Physique des Solides (**), Université Paris-Sud, 91405 Orsay, France \\ and \\ H. BERNAS \\ Institut de Physique Nucléaire, Université Paris-Sud, 91406 Orsay, France \\ (Reçu le 2 juillet 1976, acceptí le 15 septembre 1976)
}

\begin{abstract}
Résumé. - La température critique $T_{\mathrm{c}}$ d'alliages $\mathrm{Al}-\mathrm{C}$, d'Al-Ge et $\mathrm{Al}-\mathrm{Si}$, préparés par implantation ionique à très basse température atteint $4,2 \mathrm{~K}(\mathrm{C}), 7,35 \mathrm{~K}(\mathrm{Ge})$ et $8,35 \mathrm{~K}(\mathrm{Si})$. Cette dernière valeur de $T_{\mathrm{c}}$ est la plus forte valeur obtenue à partir de l'aluminium. Toutes ces valeurs de $T_{\mathrm{c}}$ correspondent à des concentrations d'éléments covalents de l'ordre de $25 \%$. Le désordre ne peut, à lui seul, expliquer ces augmentations de températures critiques.
\end{abstract}

\begin{abstract}
Random alloys of $\mathrm{C}, \mathrm{Si}$, and $\mathrm{Ge}$ with $\mathrm{Al}$, prepared by ion implantation at liquid helium temperatures, have maximum superconducting transition temperatures $T_{\mathrm{c}}$ of $4.2 \mathrm{~K}$ (C), $7.35 \mathrm{~K}(\mathrm{Ge})$ and $8.35 \mathrm{~K}(\mathrm{Si})$. The latter value is the highest yet obtained for an Al-based alloy. All these values are obtained for covalent element concentrations of $\sim 25 \%$. The effect of lattice disorder is not found sufficient to account for the observed $T_{\mathrm{c}}$ enhancements.
\end{abstract}

One of the crucial problems in superconductivity relates to the mechanisms by which the superconducting transition temperature $\left(T_{\mathrm{c}}\right)$ of a metal may be modified. It is well known that alloying and disordering may produce drastic variations in $T_{\mathrm{c}}$. The latter effect has been often studied on thin films produced by evaporation techniques [1-3] or by sputtering [4]. In superconductors such as $\mathrm{Al}$, large increases in $T_{\mathrm{c}}$ have been found for films produced by quenchcondensation $(80 \mathrm{~K}$ or $4.2 \mathrm{~K})$ of the metal with nonmetals such as $\mathrm{O}_{2}, \mathrm{H}_{2}$, rare gases, $\mathrm{Ge}$ or $\mathrm{Si}$ on cold substrates $[2,3,5]$. For pure bulk $\mathrm{Al}, T_{\mathrm{c}}=1.2 \mathrm{~K}$; typical values found in this way range from 2.0 to $4.5 \mathrm{~K}$, except for $\mathrm{Al}-\mathrm{Si}$ and $\mathrm{Al}-\mathrm{Ge}$ which reach 6.05 and $6.6 \mathrm{~K}$ respectively [3] within the framework of Macmillan's theory [6], this effect has been variously ascribed to changes in the phonon spectrum

$\left(^{*}\right)$ Work partially supported by DGRST under Contract Nb. 74.7.1083.

$\left({ }^{* *}\right)$ Associé au C.N.R.S. or in the electronic density of states at the Fermi level, or to changes in the amplitude of the clectron-phonon interaction. Alternative explanations based on electron-electron interactions via other elementary excitations have also been discussed [7-10]. At present, no overwhelming evidence favours any one of these interpretations.

The microscopic structure and the overall homogeneity of the thin film alloys are basic features in these experiments. The recent use of low temperature implantation techniques is an important development here, since they may produce inherently random phases under well-controlled conditions $[11,12]$. We have previously reported $T_{\mathrm{c}}$ increases for $\mathrm{Al}$ films implanted with $\mathrm{Al}, \mathrm{O}, \mathrm{He}$ and $\mathrm{H}$ [12]. While $T_{\mathrm{c}}$-enhancements were related to lattice disorder in $\mathrm{Al}-\mathrm{O}$ and $\mathrm{Al}-\mathrm{He}$, the effect of $\mathrm{H}$-implantation was particularly striking because of the high resulting $T_{\mathrm{c}}$ value $(6.75 \mathrm{~K})$ and the possibility that an ordered compound had been produced by ion implantation. The resistivity annealing properties were also reported [13]. In the 
present work, we have studied the critical temperatures of $\mathrm{Al}$ based thin film alloys with varying concentrations of the covalent elements $\mathrm{C}, \mathrm{Si}$ and $\mathrm{Ge}$. We report (i) results on the highest $T_{\mathrm{c}}$ values obtained for these systems; (ii) a study of the correlation between $T_{\mathrm{c}}$ and the annealing temperature for the $\mathrm{Al}-\mathrm{Si}$ system; and (iii) a study of the influence of lattice disorder on the high $T_{\mathrm{c}}$ samples.

Implantation, resistivity measurements, and film preparation techniques are the same as in our previous work [12]. Thin films $\left(8 \times 0.6 \mathrm{~mm}^{2}\right.$, thickness 500-1 $000 \AA$ ) were prepared by evaporation on crystalline quartz substrates from a tungsten crucible in a bell-jar vacuum. During the implantation the target temperature was below $10 \mathrm{~K}$. Implantation energies were ajusted in order to obtain fairly uniform samples (e.g., $30 \mathrm{keV}$ and $15 \mathrm{keV} \mathrm{Si}{ }^{+}$implantations were performed in a $500 \AA$ thick aluminium film).

Since heavy ions sputter varying amounts of the targets, the film composition after ion implantation had to be determined. The composition of the Al-Ge implanted alloys was estimated from a Rutherford backscattering study of the appropriate sputtering coefficients [14]. For the Si and C implanted samples, the alloy concentration was estimated by assuming that the sputtering ratio of $\mathrm{Si}$ on $\mathrm{Al}$ was equal to that of $\mathrm{Al}$ on $\mathrm{Al}$, and that the sputtering of $\mathrm{Al}$ by $\mathrm{C}$ was negligible.

Resistivity measurements were performed using a standard four-point probe technique [13]. Implanted samples were repeatedly measured after a succession of $\mathrm{Ge}, \mathrm{Si}$ and $\mathrm{C}$ implantations at varying doses in order to correlate the resistivity just above $T_{\mathrm{c}}$ and the superconducting transition temperature with the concentration of implanted atoms [14].

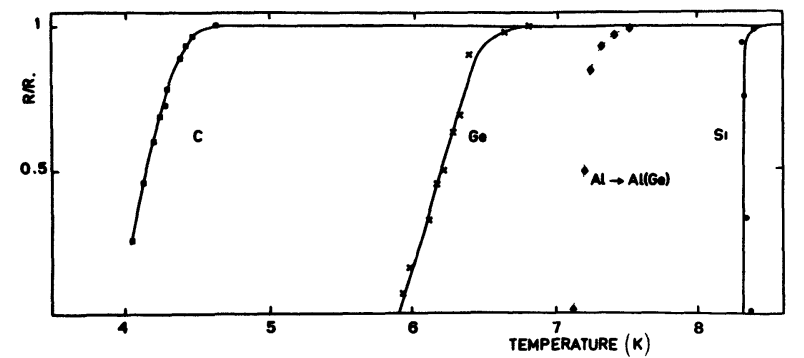

FIG. 1. - Superconducting transitions in Al-C, Al-Si and Al-Ge. The curve indexed $\mathrm{Al}(\mathrm{Ge})$ was obtained after $\mathrm{Al}$ implantation (dose $7 \times 10^{17}$ at. $\mathrm{cm}^{-2}$ ) into a room-temperature co-evaporated $\mathrm{Al}_{0.30} \mathrm{Ge}_{0.70}$ film. The curve indexed $\mathrm{Ge}$ was obtained after $\mathrm{Ge}$ implantation (dose $10^{17}$ at . $\mathrm{cm}^{-2}$ ) into a pure $\mathrm{Al}$ film.

The highest superce $;$ ing transition temperature curves obtained for different alloys are displayed in figure 1. They all correspond to estimated average $\mathrm{Ge}, \mathrm{Si}$ or $\mathrm{C}$ concentrations of about $25 \%$. Note that Al-implanted pure Ge or Al-implanted co-evaporated AlGe films produce higher $T_{\mathrm{c}}$ values than Ge-implanted Al. This could be due to recoil-implanted surface impurities (the forward collision cross-section increases for heavy incoming ions) : the increased concentrations of for example, $\mathrm{O}, \mathrm{N}$, or $\mathrm{C}$ in the Ge-implanted sample may reduce the maximum $T_{\mathrm{c}}$ value. It is quite possible that the observed value of $7.35 \mathrm{~K}$ is still below the maximum obtainable value for Al-Ge.

Three results demonstrate the effect of lattice disorder on the superconducting properties of these alloys : (i) a dose of $10^{16} \mathrm{Si}$ at. $\mathrm{cm}^{-2}$ was implanted through the highest- $T_{\mathrm{c}} \mathrm{Al}-\mathrm{Si}$ sample. The corresponding change in $\mathrm{Si}$ concentration was negligible, but the implantation produced $\sim 10$ displacements per atom in the implanted layer. This had no effect on $T_{\mathrm{c}}$. (ii) The critical temperature of an Al-Si alloy produced at $6 \mathrm{~K}$ was studied after annealing at increasing temperatures (Fig. 2). No drastic variations were found up to about $80 \mathrm{~K}$, but $T_{\mathrm{c}}$ fell to $3.3 \mathrm{~K}$ after annealing at room temperature. (iii) The same sample was then Si-implanted at $6 \mathrm{~K}: T_{\mathrm{c}}$ was found to increase sharply (Fig. 3) until the average number of displaced atoms in the implanted layer was about one.

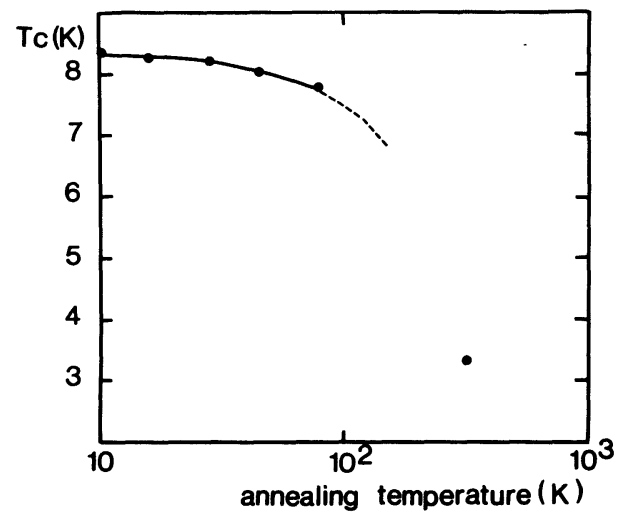

FIG. 2. - Effect of annealing on the superconducting critical temperature $T_{\mathrm{c}}$ of an implanted Al-Si film. All transitions are less than $0.1 \mathrm{~K}$ wide.

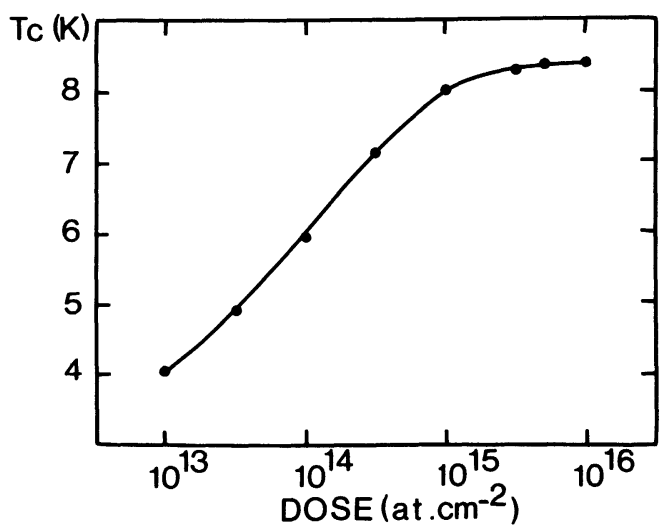

FIG. 3. - Effect of low temperature Si-implantation into Al-Si film. This film was produced by low-temperature implantation, and then annealed at room-temperature. Note negligible composition change : main effect is lattice disordering.

The first result is evidence that the Al-Si alloy produced at $6 \mathrm{~K}$ is disordered. Since $\mathrm{Al}$ and $\mathrm{Si}$ (or $\mathrm{Ge}$ ) do not form solid solutions, annealing of the implanted 
samples is expected to result in segregation and crystallite growth : our second result suggests that such a process could take place between $80 \mathrm{~K}$ and $300 \mathrm{~K}$ [15]. This is corroborated by the third result, since the only possible effect of the low-dose $\mathrm{Si}$ implantation is to randomize the atomic distribution in the Al-Si alloy.

The effect of disorder was also witnessed in the $\mathrm{Al}-\mathrm{Ge}$ system. In several experiments, $\mathrm{Al}$ was implanted at $6 \mathrm{~K}$ into room-temperature co-evaporated Al-Ge films of varying composition. The implanted $\mathrm{Al}$ dose varied from $10^{14}$ to $10^{18}$ at. $\mathrm{cm}^{-2}$ : in all cases, disordering increased $T_{\mathrm{c}}$.

Lattice disorder is thus found to favour high $T_{\mathrm{c}}$-values in $\mathrm{Al}-\mathrm{Si}$ and $\mathrm{Al}-\mathrm{Ge}$. However, a simple interpretation in terms of a softening of the $\mathrm{Al}$ phonon spectrum is not satisfying, since the highest $T_{\mathrm{c}}$-value measured for the equally disordered Al-C, Al-He and Al-O implanted systems [12] is only $4.2 \mathrm{~K}$. From recent experiments on implanted $\mathrm{Ge}-\mathrm{Cu}$ superconducting alloys [18], it was conjectured that super- conductivity is due to a liquid-like metallic phase of the semiconducting component. This suggestion was in line with the fact that superconductivity is obtained on the Ge-rich side of the $\mathrm{Ge}_{1-x} \mathrm{Cu}_{x}$ phase diagram (the highest $T_{\mathrm{c}}$ was found around $x \sim 0.3$ ). In our experiments, however, only Al-rich alloys $(x \gtrsim 0.75)$ are superconducting. It is difficult to explain the difference between our results and those of [18] if superconductivity is only due to $\mathrm{Ge}$ (or $\mathrm{Si}$ ). Alternatively, it is interesting to relate the appearance of superconductivity to the metal-insulator transition. This will be discussed for the Al-based alloys in a forthcoming paper [14].

We wish to thank M. Salomé for his help in these experiments. The Rutherford backscattering measurements were carried out at the Groupe de Physique des Solides de l'Ecole Normale Supérieure in collaboration with $\mathrm{C}$. Cohen : it is a pleasure to acknowledge his enthusiastic support and expertise. We are grateful to B. Stritzker and H. Wuihl for a preprint of their paper.

\section{References}

[1] BuCkel, W. and Hilsch, R., Z. Phys. 138 (1954) 109.

[2] Abelès, B. Cohen, R. W. and Cullen, G. W., Phys. Rev. Lett. 17 (1966) 632.

[3] Meunier, F., Hauser, J. J., Burger, J. P., Guyon, E. and HeSSE, M., Phys. Lett. B 28 (1968) 37.

[4] Hauser, J. J., Phys. Rev. B 3 (1971) 1611.

[5] Deutscher, G. and Pasternak, A., Phys. Rev. 10 (1974).

[6] Mac Millan, W. L., Phys. Rev. 167 (1968) 331.

[7] Ginsburg, V. L., Usp. Fiz. Nauk 101 (1970) 185.

[8] Allender, D., Bray, J. and Bardeen, J., Phys. Rev. B 7 (1973) 1020.

[9] Economou, E. N. and NgaI, K. L., Solid State Commun. 17 (1975) 1155 .

[10] Inkson, J. C., Anderson, P. W., Phys. Rev. B 8 (1973) 4429.

[11] MeYer, O., Application of Ions Beams to Material, ed. G. Carter, J. S. Colligon and W. A. Grant, Institute of Physics Conference Series no 28 (1975).
[12] Lamoise, A. M., Chaumont, J., Meunier, F., Bernas, H., J. Physique Lett. 36 (1975) L-271.

[13] Lamoise, A. M., Chaumont, J., Meunier, F., Bernas, H., J. Physique Lett. 36 (1975) L-305.

[14] Meunier, F., Chaumont, J., Lamoise, A. M., Cohen, C. and BERNAS, H., to be published.

[15] Although no information is available on the structure of the segregated phases, it is interesting to note that the $T_{\mathrm{c}}$-values of the annealed samples are similar to those of quenchcondensed films $[16,17]$.

[16] Fontaine, A. and Meunier, F., Phys. Kond. Mat. 14 (1972) 119.

[17] TsueI, C. C. and Johnson, W. L., Phys. Rev. B 9 (1974) 4742.

[18] Stritzker, B., and WüHL, H., Z. Phys. (to be published). 